\title{
The Effects of Recent Mortgage Refinancing
}

Peter J. Brady, Glenn B. Canner, and Dean M. Maki, of the Board's Division of Research and Statistics, prepared this article. Marcin Stawarz provided research assistance.

In recent years, rising home prices, generally falling interest rates, and a desire to convert accumulated home equity into spendable funds have combined to provide millions of homeowners with the opportunity and motivation to refinance the mortgage on their primary residence. In many cases, refinancing results in a lower interest rate and lower monthly mortgage payments, allowing homeowners to spend or save that portion of their incomes no longer dedicated to servicing mortgages. When they refinance, some homeowners liquefy the equity they have accumulated in their homes by borrowing more than they need to pay off their former mortgage and cover the transaction costs of the refinancing. They use the funds raised in such "cash-out" refinancings to make home improvements, to repay other debts, or to purchase goods and services or other assets.

The Federal Reserve Board closely follows refinancing activity as well as home equity lending, another form of borrowing used to liquefy accumulated equity in homes. Both topics have been the focus of Board-sponsored surveys of households and of previous articles in the Federal Reserve Bulletin. ${ }^{1}$

To learn more about the extent to which homeowners have been using refinancings to liquefy the equity in their homes and the way they have used the funds raised, the Federal Reserve sponsored questions concerning mortgage refinancing on the March through May 1999 Surveys of Consumers, monthly surveys conducted by the Survey Research Center of the University of Michigan (for details see appendix A).

1. See Glenn B. Canner, James T. Fergus, and Charles A. Luckett, "Home Equity Lines of Credit," Federal Reserve Bulletin, vol. 74 (June 1988), pp. 361-73; Glenn B. Canner, Charles A. Luckett, and Thomas A. Durkin, "Home Equity Lending," Federal Reserve Bulletin, vol. 75 (May 1989), pp. 333-44; Glenn B. Canner, Charles A. Luckett, and Thomas A. Durkin, "Mortgage Refinancing," Federal Reserve Bulletin, vol. 76 (August 1990), pp. 604-12; Glenn B. Canner, Charles A. Luckett, and Thomas A. Durkin, "Home Equity Lending: Evidence from Recent Surveys," Federal Reserve Bulletin, vol. 80 (July 1994), pp. 571-83; and Glenn B. Canner, Thomas A. Durkin, and Charles A. Luckett, "Recent Developments in Home Equity Lending," Federal Reserve Bulletin, vol. 84 (April 1998), pp. 241-51.
Such surveys are an important source of information on both the characteristics of a homeowner's mortgage and the homeowner's use of borrowed funds.

This article presents estimates, based on the survey findings, of changes in monthly payments resulting from refinancings, the amount of funds homeowners raised in the process, and how homeowners used the funds. Also presented are rough estimates of the aggregate effects of refinancing on the U.S. economy, including the effects on consumption spending.

\section{THE DECISION TO REFINANCE}

Choosing whether and when to refinance a home mortgage is an important and often difficult decision that involves a careful balancing of costs and benefits. Some of the factors to be considered are known with certainty and are readily quantifiable; others, such as the future course of interest rates, cannot be known with certainty.

\section{Balancing Costs and Benefits}

In general, the question of whether to refinance arises whenever current interest rates on mortgages fall below the rate on the homeowner's existing loan. At such times, the homeowner must weigh the prospective after-tax savings from lower monthly payments on a new, lower-rate loan against the after-tax costs of the refinancing transaction itself, including any mortgage fees (points) and application and appraisal fees. Because the savings from lower interest payments accumulate slowly over time as the loan is repaid, the amounts that would be saved in a refinancing must be discounted to their present value and compared with the costs of the transaction, often referred to as the closing costs. ${ }^{2}$ If the discounted

2. The comparison is not always straightforward, as the homeowner in many instances has a choice of either paying the transaction costs as a lump sum at the time of the refinancing or adding the costs to the amount being refinanced. The cost-benefit comparison is relatively easy in the former case but more complicated in the latter. To facilitate the comparison, the after-tax present value of the financed transaction costs must be determined. If the interest rate on the new loan is used as the discount rate in the calculation, the pre-tax present value of the financed transaction costs equals the lump sum payment 
present value of the stream of prospective after-tax savings in interest payments exceeds the after-tax costs of the transaction, the homeowner stands to gain from the transaction. The necessary calculations rely on certain assumptions, however, including assumptions about the course of future events, and thus the decision to refinance is often complex.

One assumption is the length of time the homeowner will own the property. If the property is sold relatively soon after a refinancing - because of a job relocation, for example - the savings in interest payments over time are unlikely to offset the costs of the transaction, unless interest rates had fallen rather substantially.

Another assumption is the homeowner's expectations about future interest rates. If the homeowner expects mortgage rates to decline, he may postpone the decision to refinance even when the benefit from refinancing exceeds its cost. The effects of uncertainty on refinancing may result in very different decisions, depending on the type of mortgage being refinanced. If the homeowner has a fixed-rate mortgage, expects mortgage rates to rise or fall with equal probability, and faces small potential savings, she may postpone refinancing because the certain gains are small, large gains are still possible if rates fall sharply, and no significant adverse effects will occur if rates rise sharply. If the homeowner has an adjustable-rate mortgage, however, the decision may be different. In that case, the prospect of higher future monthly payments should interest rates rise significantly may prompt the homeowner to refinance into a fixed-rate loan, even if the current savings are small. (Of course, a homeowner who keeps an adjustablerate loan may reap the benefits of an interest rate decline without incurring the costs of refinancing, as the loan rate will ordinarily fall with market rates.)

\section{Other Considerations}

Homeowners sometimes refinance for reasons other than to obtain a lower mortgage interest rate or to reduce uncertainty about future payments. Another motivation is to change the time period over which the mortgage is to be repaid. Some homeowners replace their current mortgage with a shorter-term loan (so that their loan will be paid off by the time

today. On an after-tax basis, however, the two amounts may differ. If the transaction costs on a refinancing are financed, the interest paid on those borrowed funds is fully tax-deductible. In contrast, if a lump sum payment of transaction costs is made, only the portion of those costs that constitutes points (prepaid interest) is tax-deductible, and it must be amortized over the life of the loan. they retire, for example). ${ }^{3}$ Other homeowners (those having difficulty making their mortgage payments or other payment obligations or anticipating a reduction or disruption in income) may replace their current loan with a longer-term loan to reduce the size of their monthly payments.

For many homeowners, a principal reason for refinancing is to raise funds by liquefying some of the equity in their home. In many refinancings, the homeowner can both extract equity and lower the interest rate on the loan. However, some homeowners refinance even when a lower rate is not available. Board-sponsored surveys over the years have found that although the number of refinancings declines sharply when interest rates are stable or rising, refinancings continue to occur-and that a large proportion of homeowners who refinance during these periods do so to liquefy the accumulated equity in their home. Also, for any given level of interest rates, cash-out refinancings are more likely following periods of rapid appreciation of home prices.

The decision to borrow additional amounts through refinancing is influenced by such factors as the rates and terms available through alternative means of financing, the level of interest rates on the existing and prospective substitute loans, the amount of equity in the home, and the amount of extra funds sought. Most homeowners who can qualify for a refinancing will also be able to obtain funds through a home equity loan, a personal loan, or a credit card account. A first mortgage usually carries the lowest available interest rate, so refinancing is often the best choice for raising a large amount of new funds. ${ }^{4}$ However, if the existing mortgage carries a very low rate and is large relative to the amount of new funds needed, the homeowner would probably not benefit by refinancing and giving up the attractive current rate.

Nonrate considerations also affect the choice among alternative sources of funds. For example, unlike a refinancing, in which the homeowner obtains the full amount of the extracted funds immediately (and therefore incurs interest charges on the funds immediately), a home equity line of credit or a credit card account provides flexibility for subsequent borrowing and might be more appropriate for han-

3. Of course, a homeowner can in most cases repay a longer-term mortgage over a period shorter than the stated term by making larger payments than are required. In such a case, however, the homeowner would not benefit from the lower interest rates typically available on shorter-term loans.

4. In addition to considering differences in interest rates, a homeowner must weigh differences in transaction costs among alternative types of loans. For example, although a home equity loan often has an interest rate higher than that on a refinanced first mortgage, the transaction costs for a home equity loan may be lower. 
dling repetitive credit needs, such as periodic tuition expenses, even when rate comparisons seem to favor refinancing.

Another nonrate consideration is taxes. For example, federal tax law favors mortgage borrowing, as the interest payments are generally tax-deductible. Interest payments on credit cards and most other forms of nonmortgage debt, in contrast, are not taxdeductible, and therefore the after-tax cost of borrowing through a mortgage refinancing or a home equity loan is less than a comparable debt not secured by the borrower's home. ${ }^{5}$

\section{SURVEY FINDINGS}

Responses to the 1999 Surveys of Consumers make it possible to determine the incidence of mortgage refinancing, the amount of funds raised in refinancings, and the uses of the funds by homeowners.

\section{Home Ownership and the Incidence of Mortgage Debt}

Home-ownership rates have been increasing in recent years and reached a new high in 1999. Consistent with estimates by the Bureau of the Census, findings from the 1999 survey indicate that in the first half of 1999, 67 percent of all households owned their home. ${ }^{6}$ The majority of those homeowners (about 60 percent) had an outstanding mortgage on their primary residence (table 1). Such borrowing varied considerably across regions of the country, however.

\section{The Prevalence of Refinancing}

Board-sponsored surveys indicate that mortgage refinancing has not been rare in recent years. In 1999, 47 percent of all homeowners with mortgage debt reported that they had refinanced the mortgage on their current home at least once. Similarly, a 1994

5. See Dean M. Maki, "Household Debt and the Tax Reform Act of 1986," American Economic Review (forthcoming), for an analysis of the substitution of mortgage for consumer debt after the elimination of the tax-deductibility of consumer interest in the Tax Reform Act of 1986. Another tax-related consideration involves the simultaneous holding of tax-favored mortgage debt and tax-favored pension assets; see Eric M. Engen, William G. Gale, and John Karl Scholz, "The Illusory Effects of Saving Incentives on Saving," Journal of Economic Perspectives, vol. 10 (Fall 1996), pp. 113-38.

6. U.S. Department of Housing and Urban Development, U.S. Housing Market Conditions, table 29, "Homeownership Rates by Age of Householder: 1982-Present” (3rd quarter 1999).
1. Mortgage status and refinancing activity of homeowners, by region, 1999

Percent

\begin{tabular}{|c|c|c|c|c|c|}
\hline Item & $\begin{array}{l}\text { All } \\
\text { regions }\end{array}$ & West & $\begin{array}{l}\text { North } \\
\text { Central }\end{array}$ & Northeast & South \\
\hline $\begin{array}{l}\text { Mortgage status } \\
\text { No mortgage } \ldots\end{array}$ & 39 & 29 & 37 & 41 & 45 \\
\hline $\begin{array}{c}\text { Mortgage or land } \\
\text { contract } \ldots\end{array}$ & 61 & 71 & 63 & 59 & 55 \\
\hline Total & 100 & 100 & 100 & 100 & 100 \\
\hline $\begin{array}{l}\text { Refinancing activity } \\
\text { Mortgage debt } \\
\text { holders who } \\
\text { had refinanced } \\
\text { first mortgage } \\
\text { or land contract }\end{array}$ & 47 & 52 & 52 & 55 & 37 \\
\hline $\begin{array}{l}\text { Mortgage debt } \\
\text { holders who } \\
\text { had refinanced } \\
\text { first mortgage or } \\
\text { land contract in } \\
1998 \text { or early } \\
1999 \text {............. }\end{array}$ & 20 & 24 & 23 & 21 & 13 \\
\hline
\end{tabular}

NotE. All survey data in this and the following tables are based on weighted observations.

Source. Here and in subsequent tables (except as noted), Surveys of Consumers, University of Michigan Survey Research Center, March, April, and May 1999.

Board-sponsored survey found that 45 percent of mortgage debt holders had refinanced their mortgage. ${ }^{7}$ The prevalence of refinancing in recent years can be traced to a number of factors, including lower interest rates; the widespread adoption of new technologies that have reduced transaction costs; and gains in home values and equity, which have increased opportunities to borrow additional amounts.

Refinancing activity tends to closely follow changes in interest rates (chart 1). Because interest rates have fluctuated over the past decade and have been low relative to the previous two decades, homeowners have had several attractive opportunities to refinance. The relatively low long-term interest rates of the second half of 1998 and early 1999 stimulated a refinancing boom. The 1999 survey findings reflect the industry statistics shown in the chart: 42 percent of the homeowners who had refinanced their mortgage obligations-an estimated 8.3 million homeowners-did so in 1998 or the first five months of 1999 (table 2).

7. The incidence of refinancing was lower in Board-sponsored household surveys in the 1970s and 1980s. For example, the 1977 Survey of Consumer Finances found that only 8 percent of homeowners had refinanced the mortgage on their current home, and a special survey of refinancing activity conducted in 1989 found that only 20 percent of homeowners had refinanced. See Thomas A. Durkin and Gregory E. Elliehausen, 1977 Consumer Credit Survey (Board of Governors of the Federal Reserve System, 1978), p. 72; and Canner, Luckett, and Durkin, "Mortgage Refinancing," p. 607. 
1. Refinancing activity and mortgage rates, 1993-2000

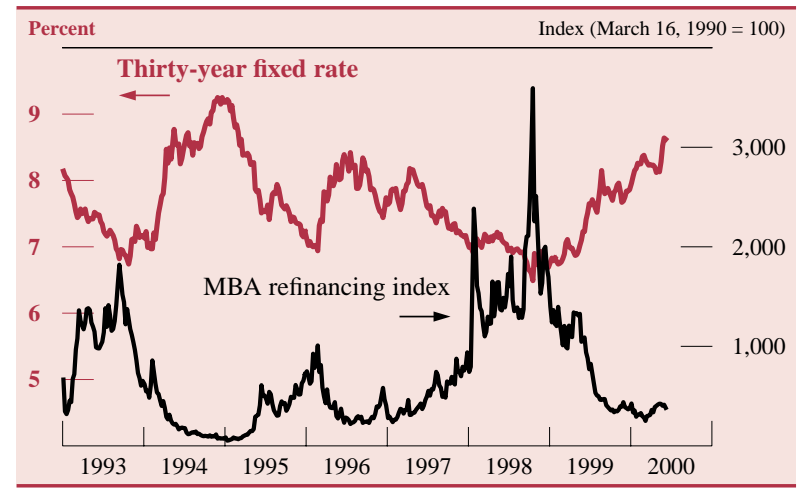

Note. The data are weekly and extend through May 26, 2000. The refinancing index is seasonally adjusted.

Source. Federal Home Loan Mortgage Corporation; Mortgage Bankers Association.

Another gauge of the extent of refinancing activity is data obtained pursuant to the Home Mortgage Disclosure Act (HMDA). HMDA data include information on the number of home-purchase and refinancing loans extended each year. ${ }^{8}$ Since 1993, HMDA's institutional coverage has been relatively complete (covering 75 percent to 80 percent of all mortgage lending), and thus the data are a useful measure of the prevalence of refinancing activity. ${ }^{9}$

8. For additional information, see Glenn B. Canner and Dolores S. Smith, "Expanded HMDA Data on Residential Lending: One Year Later," Federal Reserve Bulletin, vol. 78 (November 1992), pp. 801-24.

9. Legislative changes in the coverage of HMDA that became effective in 1993 required more mortgage companies to report under the law. Before then, mortgage companies not affiliated with banking institutions did not have to report.

2. Year of most recent refinancing and prevailing home mortgage interest rate

\begin{tabular}{|c|c|c|}
\hline $\begin{array}{l}\text { Year in which } \\
\text { refinancing } \\
\text { occurred }\end{array}$ & $\begin{array}{l}\text { Percent of all } \\
\text { refinanced loans } \\
\text { in survey }{ }^{1}\end{array}$ & $\begin{array}{l}\text { Interest rate } \\
(\text { percent })^{2}\end{array}$ \\
\hline Before 1990 & 3 & \\
\hline 1990 & 1 & 9.68 \\
\hline 1991. & 3 & 9.02 \\
\hline 1992. & 4 & 7.98 \\
\hline 1993. & 6 & $\begin{array}{l}7.03 \\
\end{array}$ \\
\hline $1994 \ldots \ldots$ & 4 & 7.26 \\
\hline 1995 & 7 & 7.65 \\
\hline 1996 & 13 & 7.56 \\
\hline 1997 & 17 & 7.57 \\
\hline & 30 & 6.95 \\
\hline $1999^{3}$. & 12 & 6.87 \\
\hline Total & 100 & $\ldots$ \\
\hline
\end{tabular}

1. Refinancing activity in years preceding 1998 is not fully reflected in this table. Some homeowners refinanced their mortgage more than once, but information on only the most recent refinancing activity was collected in the survey.

2. Weighted-average contract rate on conventional mortgages for the purchase of newly built homes, from the monthly Federal Housing Finance Board news release on mortgage markets.

3. Through May 1999.

... Not applicable.
3. Number of mortgage loans extended, by purpose of loan, 1993-98

Millions of loans

\begin{tabular}{|c|c|c|}
\hline \multirow{2}{*}{ Year } & \multicolumn{2}{|c|}{ Purpose of loan } \\
\hline & Home purchase & Refinancing \\
\hline 1993 & 3.2 & 6.1 \\
\hline 1994 & 3.5 & 2.5 \\
\hline 1995 & 3.5 & 1.6 \\
\hline 1996 & 3.8 & 2.6 \\
\hline 1997 & 4.0 & 2.8 \\
\hline 1998 & 4.5 & 6.7 \\
\hline
\end{tabular}

Source. Home Mortgage Disclosure Act data, from Federal Financial Institutions Examination Council.

The HMDA data document the refinancing booms in 1993 and 1998 (1999 data are not yet available) (table 3 ). ${ }^{10}$ In both years, the number of refinancings exceeded the number of home-purchase loans by a wide margin; in the interim years, home-purchase loans were more numerous than refinancings.

\section{Refinancing and the}

Amount of Mortgage Debt

Homeowners who have refinanced their mortgages tend to have more mortgage debt than those who have not. The 1999 survey found that 47 percent of mortgage debt holders had refinanced their loan but that the refinancers accounted for 55 percent of outstanding mortgage debt. This imbalance has two possible explanations. One is that many refinancing homeowners liquefied equity by adding debt. The other is that homeowners who have relatively large mortgage balances have a greater propensity to refinance because the potential interest savings are more likely to exceed the transaction costs associated with refinancing.

\section{Reasons for Refinancing}

As noted earlier, homeowners have various reasons for refinancing their mortgage, including to obtain a lower interest rate, to change the terms of their loan (such as to convert from an adjustable-rate to a fixed-rate mortgage), and to liquefy equity. Survey responses from homeowners who refinanced in 1998

10. The 1993 refinancing boom is not apparent from the data in table 2, for several reasons. Many homeowners refinanced their mortgage more than once, but because the 1999 survey collected information on only the most recent refinancing, only the date of that refinancing is known. Also, the survey asked only about the mortgage on a homeowner's current home, and some homeowners may have refinanced the mortgage on a previous home. 
4. Type of original and refinanced loans among 1998 and early 1999 refinancers

Percent

\begin{tabular}{c|c|c|c}
\hline \multirow{2}{*}{ Type of refinanced loan } & \multicolumn{3}{|c}{ Type of original loan } \\
\cline { 2 - 4 } & $\begin{array}{c}\text { Adjustable } \\
\text { rate }\end{array}$ & $\begin{array}{c}\text { Fixed } \\
\text { rate }\end{array}$ & Total \\
\hline Adjustable rate $\ldots \ldots \ldots \ldots \ldots$ & 8 & 2 & 10 \\
Fixed rate $\ldots \ldots \ldots \ldots \ldots \ldots$ & 21 & 69 & 90 \\
Total $\ldots \ldots \ldots \ldots \ldots \ldots \ldots$ & $\mathbf{2 9}$ & $\mathbf{7 1}$ & $\mathbf{1 0 0}$ \\
\hline
\end{tabular}

and early 1999 provide an opportunity to measure the proportion of homeowners who changed their mortgage along each of these dimensions when they refinanced.

As might be expected, most surveyed homeowners who refinanced at the end of the decade92 percent-obtained a lower interest rate. The average interest rate declined 1.3 percentage points, from 8.4 percent to 7.1 percent.

A substantial number of refinancing homeowners shifted from an adjustable-rate mortgage to a fixedrate mortgage when they refinanced: Twenty-nine percent had an adjustable-rate mortgage before refinancing; roughly three-fourths of that grouprepresenting 21 percent of all homeowners who refinanced-switched to a fixed-rate loan when they refinanced (table 4). Almost all those who originally had a fixed-rate loan stayed with a fixed-rate loan. The net result was that the proportion of this group that had a fixed-rate loan rose from 71 percent before refinancing to 90 percent after refinancing.

The survey results also indicate that, on average, refinancing homeowners lengthened the maturity of their mortgage. ${ }^{11}$ About 67 percent had a longer maturity after they refinanced, and 25 percent had a shorter maturity.

A relatively large proportion of homeowners who refinanced in 1998 and early 1999_about 35 percent-used the opportunity to liquefy some of their home equity (table 5). ${ }^{12}$ By comparison, about 25 percent of refinancing homeowners in a similar survey in 1994 liquefied equity (data not shown in table). The difference in the proportion of cash-out refinancings in the two surveys may have been due to differences in housing market conditions: Home prices had generally appreciated much more rapidly in the years just before the current wave of refinanc-

11. A homeowner was considered to have lengthened the maturity if the term on the new mortgage exceeded the remaining term on the former mortgage.

12. A homeowner was considered to have liquefied home equity if she borrowed more than was necessary to repay the balance on the existing mortgage(s) plus the closing costs on the new mortgage.
5. Extent of cash-out refinancing among 1998 and early 1999 refinancers and effect of refinancing on term to maturity and size of monthly mortgage payment Percent

\begin{tabular}{|c|c|c|}
\hline Item & $\begin{array}{l}\text { No equity } \\
\text { liquefied }^{1}\end{array}$ & $\begin{array}{l}\text { Equity } \\
\text { liquefied }^{1}\end{array}$ \\
\hline $\begin{array}{l}\text { Mortgage holders with a } \\
\text { refinanced loan ..... }\end{array}$ & 65 & 35 \\
\hline Effect on maturity & & \\
\hline Lengthened maturity & 63 & 71 \\
\hline Shortened maturity .. & 29 & 22 \\
\hline No change ......... & 8 & 7 \\
\hline Total ... & 100 & 100 \\
\hline Effect on monthly payment & & \\
\hline Higher monthly payment & 26 & 37 \\
\hline Lower monthly payment . & 67 & 26 \\
\hline No change $\ldots \ldots \ldots \ldots$. & 7 & 37 \\
\hline Total ...... & 100 & 100 \\
\hline
\end{tabular}

1. Equity is liquefied when a homeowner refinances mortgage debt and borrows more than is necessary to repay the balance on the existing mortgage(s) plus closing costs on the new loan.

ings than they had in the early 1990s, and thus there was more equity for homeowners to tap.

The fraction of refinancing homeowners reporting lower interest rates was similar for those who liquefied equity and those who did not (more than 90 percent of each group). Changes in maturity differed somewhat between the groups, however. Of homeowners who did not liquefy equity, 63 percent lengthened the maturity of their loan and 29 percent shortened it. Homeowners who liquefied equity were more likely than those who did not to lengthen the maturity of their loan: 71 percent lengthened it and 22 percent shortened it. (It should be kept in mind that a relatively small number of the survey respondents refinanced and liquefied equity in 1998 and early 1999 , and that estimates based on this small group are less precise than estimates based on the full sample of refinancers.)

As a result of the changes in interest rates, maturities, and loan balances, 52 percent of homeowners refinancing in 1998 and early 1999 had a lower monthly payment after obtaining the new loan and 30 percent had a higher payment (not shown in table). Because they took on additional debt, only 26 percent of homeowners who liquefied equity had a lower monthly payment, compared with 67 percent of homeowners who did not liquefy equity.

\section{Uses of Borrowed Funds}

Funds liquefied in refinancings are used in various ways. For homeowners in the 1999 survey who refinanced in 1998 and early 1999, the most common use of funds was to repay other debts, reported by 45 per- 
cent of those who took out cash (table 6). ${ }^{13}$ Home improvements were cited by 40 percent of those who took out cash, and consumer expenditures such as vehicle purchases, vacations, education, and medical expenses were cited by 39 percent. Stock market or other financial investment was cited by 12 percent of the group, and real estate or business investment by 10 percent.

Looking at the uses of funds in terms of dollars rather than proportion of loans gives a somewhat different picture. Approximately one-third of the money was spent on home improvement, and just over one-fourth was used to pay off other debt (table 6). Roughly one-fifth went for consumer expenditures, and a similar amount was used to invest in real estate or business. Less than 2 percent was spent on stock market investment, even though 12 percent of the loans were used for this purpose; most homeowners who used the cash to make stock market investments invested relatively small amounts.

The amounts borrowed through cash-out refinancing in some cases were large. About 43 percent of homeowners who extracted equity in 1998 and early 1999 took out less than $\$ 10,000$, but 26 percent liquefied $\$ 25,000$ or more (table 7). The mean amount liquefied was more than $\$ 18,000$, and the median amount was $\$ 10,000$.

\section{Aggregate Estimates of Payment Savings and Uses of Funds}

Converting the survey information to aggregate estimates is problematic, both because a relatively small

13. Because money is fungible, it is possible that the reported percentage of homeowners using the cash to substitute for other debt is understated; in some cases, homeowners who reported using the cash to fund purchases may have otherwise funded the purchase with another type of debt.

6. Uses of funds liquefied in 1998 and early 1999 refinancings

\begin{tabular}{|c|c|c|}
\hline Use & $\begin{array}{l}\text { Percent } \\
\text { of loans }{ }^{1}\end{array}$ & $\begin{array}{l}\text { Percent } \\
\text { of dollars }\end{array}$ \\
\hline Repayment of other debts & 45 & 28 \\
\hline Home improvements .... & 40 & 33 \\
\hline Consumer expenditures $^{2} \ldots \ldots$ & 39 & 18 \\
\hline Stock market or other financial & & \\
\hline investment $\ldots \ldots \ldots \ldots \ldots$ & 12 & 2 \\
\hline Real estate or business investment & 10 & 19 \\
\hline
\end{tabular}

1. Percentages sum to more than 100 percent because multiple uses could be cited for a single loan.

2. Includes vehicle purchases, vacations, education or medical expenses, living expenses, and other.
7. Amount of home equity liquefied in 1998 and early 1999 refinancings

\begin{tabular}{|c|c|}
\hline $\begin{array}{l}\text { Amount liquefied } \\
\text { (current dollars) }^{1}\end{array}$ & Percent $^{2}$ \\
\hline $\begin{array}{l}1-9,999 \ldots \ldots \ldots \\
10,000-24,999 \ldots \\
25,000 \text { or more } \ldots\end{array}$ & $\begin{array}{l}43 \\
31 \\
26\end{array}$ \\
\hline Total........ & 100 \\
\hline $\begin{array}{l}\text { Mемо } \\
\text { Mean (dollars) .... } \\
\text { Median (dollars) .. }\end{array}$ & $\begin{array}{l}18,240 \\
10,000\end{array}$ \\
\hline
\end{tabular}

1. Amount borrowed through refinancing that exceeded amount due on existing mortgage(s) plus closing costs.

2. Includes only refinancers who liquefied equity.

number of surveyed homeowners liquefied equity and because it is difficult to quantify the ultimate effects of a refinancing on a homeowner's consumption and investment activity. Nonetheless, to get a sense of the aggregate effect that refinancings undertaken in 1998 and early 1999 may have had on the U.S. economy, some rough calculations of the reduction in mortgage payments, the amount of funds raised through cash-out refinancing, and the direct uses of the funds were made. Details about these calculations are given in appendix $\mathrm{B}$.

To estimate the reduction in mortgage payments, we looked at three factors that most commonly lead to changes in mortgage payments: a change in interest rates, a change in maturity, and a change in outstanding balance. If only interest rates had changed, refinancing would have lowered aggregate annual mortgage payments nationwide an estimated $\$ 9.2$ billion, or about $\$ 1,100$ for the average refinancing homeowner. However, the average refinancing homeowner increased the remaining maturity of his mortgage about eleven months. Keeping outstanding balances constant, such a lengthening of maturity would have led to an additional reduction in aggregate annual mortgage payments of $\$ 1.1$ billion, or about $\$ 135$ for the average refinancing homeowner. Counteracting the effects of lower interest rates and longer maturity, the average balance on refinanced loans increased approximately $\$ 6,600$. Accounting for this larger balance, aggregate annual mortgage payments declined $\$ 5.6$ billion, on net, or about $\$ 680$ for the average refinancing homeowner, as a result of refinancings in 1998 and early 1999.

For homeowners who itemize tax deductions, these calculations overestimate savings because lower interest payments reduce itemized deductions and result in a higher tax liability. For a homeowner facing a 28 percent marginal federal income tax rate and a 5 percent marginal state income tax rate, for 
example, about one-third of the interest savings is offset by higher tax payments. Rough calculations using 1997 tax data suggest that three-fourths of homeowners who have mortgage debt claim a mortgage interest deduction. ${ }^{14}$

In considering the effect of lower mortgage payments on nonfinancial activity, such as consumption, it is important to recognize that a reduction in mortgage payments leads to a decline in the amount of interest income received by mortgage investors, a point often overlooked by analysts. Even so, the marginal propensity to consume of the typical refinancing borrower likely is higher than the marginal propensity to consume of the typical mortgage investor, and therefore refinancing, to the extent that it results in lower mortgage payments, likely raises consumption somewhat. ${ }^{15}$

Turning to the effect of cash-out refinancing, we estimate that, in total, $\$ 55$ billion of equity was liquefied through cash-out refinancing in 1998 and early 1999. This amount is similar in magnitude to estimates of the growth of consumer credit and the growth of home equity debt over the same period and represents about 12 percent of net new mortgage debt over the period.

Like the effect of lower mortgage payments on consumption, the effect of cash-out refinancing on consumption is uncertain. Economic theory suggests that refinancing might affect consumption in at least three ways. In one view, homeowners are assumed to rationally examine all financing alternatives and to have full information about future income and wealth. If a homeowner decides to purchase a good or service and chooses cash-out refinancing as the means of financing, the effect of this means of raising funds on consumption would be the increment of consumption induced by the lower after-tax interest rate available through refinancing compared with alternative sources of funds. For example, suppose a homeowner's wealth has increased because of a rapid appreciation in house prices, and as a result the homeowner wishes to increase consumption. The homeowner may decide to fund this consumption through a cash-out refinancing, a home equity loan, or a consumer loan or simply by saving less out of

14. Tax data for the calculations came from David Campbell and Michael Parisi, "Individual Income Tax Returns, 1997," Statistics of Income Bulletin (Fall 1999), pp. 8-45.

15. Investors in mortgages include both institutions and individuals. Although institutions do not directly contribute to consumption expenditures, the income generated by mortgages held by these institutions ultimately passes through to the household sector, through either increased dividend payments or an increased value of the firm. current income. The effect of the refinancing alternative on consumption would be the difference between the amount of consumption associated with the cashout refinancing and the amount that would have been chosen alternatively.

A second view of the effect of cash-out refinancing on consumption suggests a larger effect on consumption. In this view, homeowners are assumed to rationally examine all financing alternatives but to be uncertain about the value of their home. The appraisal of the home that accompanies the refinancing may raise or make more certain the homeowner's own estimate of the home's value, and he may view some or all of the liquefied equity as a windfall. In such a case, a greater proportion of the funds raised may be used to fund new spending than would be implied by a simple calculation of the difference in interest rates between alternative sources of financing.

In the third view of the effect of cash-out refinancing on consumption, homeowners are assumed to be either uninformed about or uninterested in the value of their home and unwilling to spend significant amounts to determine the value. In this view, a homeowner's spending may respond more to wealth that is in liquid form than to wealth that is relatively illiquid, such as the equity in a house.

Given the uncertainties surrounding how best to theoretically model a household's decisionmaking, it is difficult to determine, either conceptually or empirically, the net effect of cash-out refinancing on nonfinancial activity in the U.S. economy. A useful first step is to ask the homeowners who did liquefy equity how they used the funds. Survey findings suggest that about $\$ 10$ billion of the $\$ 55$ billion raised was used to fund activities that are classified in the national income accounts as consumption expenditures, such as the purchase of vehicles or other durable consumer goods, vacations, and education and medical expenses. Approximately $\$ 18$ billion was used for home improvements, which are classified in the national income accounts as residential investment. These figures can be viewed in context by comparing them with aggregate figures on spending for home improvements and consumption. Home improvement expenditures totaled an estimated $\$ 84$ billion in 1998 , about $\$ 4$ billion higher than in 1997. Personal consumption expenditures amounted to $\$ 5.85$ trillion in 1998 , $\$ 325$ billion more than in 1997; of this amount, durable goods expenditures accounted for $\$ 698$ billion in 1998, $\$ 56$ billion more than in 1997. These magnitudes suggest that cash-out refinancing in 1998 and early 1999 may have been an important source of financing for home 
improvements but was probably not a substantial direct source of funding for consumption spending. ${ }^{16}$

The remaining funds raised through refinancings were used by homeowners to reshuffle their investment portfolios; that is, they used the money to pay off other debts or to fund investments in financial, real estate, or business assets. About $\$ 15$ billion was used to pay off credit card debt or other consumer debt; consumer credit outstanding increased $\$ 55$ billion during 1998 and early 1999 from its level of $\$ 1.26$ trillion at the end of 1997, suggesting that cash-out refinancing may have reduced the growth of consumer credit approximately 20 percent, from 8 percent to $6 \frac{1 / 4}{4}$ percent at an annual rate. Another $\$ 10$ billion was invested in other real estate assets or in individual businesses. Less than $\$ 1$ billion was invested in the stock market or other financial investments.

\section{SUMMARY AND}

CONCLUDING OBSERVATIONS

Over the course of the 1990 s, and in the latter years of the decade in particular, millions of homeowners took advantage of lower mortgage interest rates and higher home values and refinanced their mortgage loans. For many, the decision to refinance was motivated by a desire to reduce their monthly mortgage payments. A significant proportion of those who refinanced also borrowed additional funds by taking out a new mortgage that was larger than the outstanding balance on their former mortgage plus closing costs. In addition, many homeowners used the refinancing opportunity to switch from an adjustable-rate to a fixed-rate mortgage.

At first glance it would seem that a boom in refinancing activity could substantially boost consumption spending and have a large effect on the U.S. economy. The issue is more complex, however. For example, when interest rates fall, most refinancings result in lower monthly mortgage payments for bor-

16. A portion of the funds used for "home improvement" may in fact have been spent on items that in the national income accounts are counted in consumption, such as carpeting, draperies, and paint. If (consistent with the text discussion) home improvement spending from funds raised in 1998 and early 1999 is not treated as consumption spending, cash-out refinancing would have increased the growth in consumption expenditures less than 0.2 percentage point (for reference, nominal consumption expenditures rose at an annual rate of about 6.5 percent between the fourth quarter of 1997 and the first quarter of 1999). If all reported home improvement spending is treated as consumption spending, the increment to consumption expenditures would still have been less than 0.5 percentage point. rowers; however, mortgage investors receive correspondingly lower interest income. As a consequence, the magnitude of the effect of such transactions on consumption spending is uncertain.

Federal Reserve-sponsored questions on a 1999 survey documented the extent of refinancing activity and asked homeowners whether they had liquefied equity through their refinancing, how much equity they had liquefied, and how they had used the funds raised. Nearly half of homeowners with a mortgage reported that they had refinanced their home loan at least once, and about a fifth of homeowners with a mortgage (roughly 40 percent of refinancers) reported having refinanced in 1998 or early 1999. About 35 percent of those refinancing in 1998 or early 1999 borrowed against the accumulated equity in their homes. As in earlier surveys of refinancing activity, the principal uses of borrowed funds were for home improvements and the repayment of other debts. Purchases of goods and services were cited as a use of borrowed funds by a fairly large proportion of refinancers, but the dollar amounts involved were typically not very large.

Survey results suggest that recent cash-out refinancing activity likely boosted consumption spending, but only a small amount relative to aggregate consumption spending. ${ }^{17}$ The effect on home improvement spending, which is treated as investment spending (rather than consumption spending) in national income accounting, was likely more substantial. In addition, consumer credit likely grew more moderately as a consequence of cash-out refinancings during 1998 and early 1999.

\section{APPENDIX A: \\ THE SURVEYS OF CONSUMERS}

To obtain information on the prevalence of residential mortgage refinancings by homeowners, the extent to which refinancings are used to liquefy accumulated equity, and the uses of the liquefied funds, the Federal Reserve Board sponsored questions that were included in the Surveys of Consumers for March, April, and May 1999. The Survey Research Center at the University of Michigan conducted the nationwide surveys.

Interviews were conducted by telephone, with telephone numbers drawn from a cluster sample of

17. As noted in the previous section, under some models of household decisionmaking the actual increment to consumption from cashout refinancing would be less than that measured by the survey responses. 


\section{A.1. Approximate sampling errors for survey results, by size of sample Percentage points}

\begin{tabular}{|c|c|c|c|c|}
\hline \multirow{2}{*}{$\begin{array}{l}\text { Survey result } \\
\text { (percent) }\end{array}$} & \multicolumn{4}{|c|}{ Size of sample } \\
\hline & 100 & 300 & 1,000 & 1,500 \\
\hline $50 \ldots \ldots$ & 11.2 & 6.5 & 3.5 & 2.9 \\
\hline 30 or 70 & 10.3 & 5.9 & 3.2 & 2.6 \\
\hline 20 or 80 & 9.0 & 5.2 & 2.8 & 2.3 \\
\hline 10 or 90 & 6.7 & 3.9 & 2.1 & 1.7 \\
\hline 5 or 95. & 4.9 & 2.8 & 1.5 & 1.3 \\
\hline
\end{tabular}

NoTE. Ninety-five percent confidence level, 1.96 standard errors.

residential numbers. The sample was chosen to be broadly representative of the four main regions of the country-Northeast, North Central, South, and West - in proportion to their populations. Alaska and Hawaii were not included. For each telephone number drawn, an adult in the family was randomly selected as the respondent. The survey defines a family as any group of persons living together who are related by marriage, blood, or adoption or any individual living alone or with a person or persons to whom the individual is not related.

Together, the three surveys sampled 1,500 families, 1,040 of whom were homeowners. Among the homeowners, 653 had an outstanding mortgage or land contract, and 311 of this group reported that their outstanding first mortgage was a refinanced loan. Among the homeowners who had refinanced, 117 had refinanced in 1998 or early 1999. The survey data have been weighted to be representative of the population as a whole, thereby correcting for differences among families in the probability of their being selected as survey respondents. All survey data in the tables are based on weighted observations.

Estimates of population characteristics derived from samples are subject to error, with the amount of the error dependent on the extent to which the sample respondents differ from the general population. Table A.1 indicates the sampling errors for survey results derived from samples of different sizes.

\section{APPENDIX B:}

\section{CALCULATION OF AGGREGATE EFFECTS}

To estimate the aggregate reduction in mortgage payments resulting from mortgage refinancing in 1998 and early 1999, the total amount of funds raised through cash-out refinancing, and the uses of these funds, we estimated dollar amounts for an average refinancing homeowner and then extrapolated those figures to arrive at national aggregates. In estimating the reduction in mortgage payments, first only the effect of interest rate changes was considered; then the effect of changes in loan maturities was added in; finally the effect of changes in outstanding loan balances was accounted for. All estimates are based on relatively small samples, and some caution should be exercised in their use.

\section{Payment Change Due to Interest Rate Changes}

To estimate the reduction in mortgage payments due to lower interest rates, we assumed that the interest rate on the new loan differed from that on the old loan but that the average refinancing homeowner changed neither the outstanding balance nor the remaining maturity of the mortgage. The average outstanding balance before refinancing for homeowners in the sample who refinanced in 1998 and early 1999 was $\$ 111,024$; the dollar-weighted average remaining maturity before refinancing was twenty-three years ten months; and the dollarweighted interest rate changed from 8.36 percent before refinancing to 7.08 percent after refinancing. For the average refinancing homeowner, interest savings from refinancing lowered monthly payments about $\$ 92$, or about $\$ 1,103$ annually. Multiplying this annual savings by $8,313,780$ households (the weighted 8.03 percent of the sample estimated to have refinanced multiplied by $103,534,000$ households in the United States) yields an aggregate annual decline in mortgage payments of $\$ 9.2$ billion.

\section{Payment Change Due to Interest Rate and Maturity Changes}

Monthly payments were also affected by changes in maturities resulting from refinancings. On a dollarweighted average basis, homeowners involved in refinancings increased the remaining maturity on their mortgage eleven months, to twenty-four years nine months. Combined with the lower interest rate, the increase in maturity decreased the average refinancing homeowner's payment about $\$ 103$ a month, or about $\$ 1,239$ annually. This figure implies an aggregate annual decline in mortgage payments of $\$ 10.3$ billion.

\section{Payment Change Due to Interest Rate, Maturity, and Outstanding Balance Changes}

Monthly payments were also affected by changes in outstanding mortgage balances that were associ- 
ated with refinancings. For the average refinancing homeowner, the outstanding balance on refinanced mortgages increased $\$ 6,558$, from $\$ 111,024$ to $\$ 117,582$; the higher balance raises monthly payments, offsetting some of the interest rate and maturity effects. ${ }^{18}$ The combined effect of the lower interest rate, the longer remaining maturity, and the higher balance is to lower the average refinancing homeowner's mortgage payment about $\$ 56$ a month, or about $\$ 677$ annually. This figure implies an aggregate annual decline in mortgage payments of $\$ 5.6$ billion.

18. Note that the average refinancing homeowner represents both homeowners who liquefied equity when they refinanced and those who did not. Also, it is assumed that those who did not liquefy equity did not change their outstanding balance. To the extent that some individuals paid down their existing mortgage when refinancing-to avoid paying private mortgage insurance, for example-this figure would be an overestimate of the increase in the average mortgage balance.

\section{Aggregate Funds Raised Through Cash-Out Refinancing, and the Uses of Funds}

The average refinancing homeowner's outstanding balance increased $\$ 6,558$. This figure implies an aggregate estimate of funds raised through cash-out refinancing of about $\$ 54.5$ billion. Using the data in table 6, the aggregate dollar amount extracted through refinancing and used for various purposes can be estimated:

\begin{tabular}{|c|c|}
\hline Use of borrowed funds & $\begin{array}{l}\text { Amount used } \\
\text { (billions of dollars) }\end{array}$ \\
\hline Repayment of other debts . & 15.4 \\
\hline Home improvements .... & 18.1 \\
\hline Consumer expenditures $\ldots \ldots \ldots \ldots \ldots \ldots$. & 9.6 \\
\hline Stock market or other financial investment & 9 \\
\hline Real estate or business investment ........ & 10.4 \\
\hline Total & 54.5 \\
\hline
\end{tabular}

Note. Components do not sum to total because of rounding. 